\title{
Assessment of selected major and trace elements in groundwater of Lagos based on land use and implication on human health
}

\author{
Abiodun Mary Odukoya ${ }^{1}$ D $\cdot$ Wiiiiams Temitope Ifarajinmi ${ }^{1}$
}

Received: 27 February 2019 / Accepted: 11 February 2021 / Published online: 3 March 2021

(c) The Author(s) 2021

\begin{abstract}
Sixty-seven (67) groundwater samples from different land use areas such as dumpsites, industrial, markets and residential all within Lagos, southwest Nigeria, were sampled and sent to ACME Laboratories, Ontario, Canada, for geochemical analysis to determine some essential and toxic elements using inductively coupled plasma-mass spectrometer method. The purpose was to establish baseline values for the geochemical composition of groundwater in some parts of Lagos as well as the health risk assessment. Based on essential elements, $83 \%, 80 \%$ and $100 \%$ of groundwater samples were deficient in $\mathrm{Ca}, \mathrm{Mg}$ and $\mathrm{Se}$, respectively, while $75 \%, 10 \%, 7 \%$ and $8 \%$ of samples can be categorised as soft, moderately hard, hard and very hard water, respectively. The soft water, as well as different deficiencies in water, had been linked to heart problems, impeded growth, fertility disorders and liver diseases. Concentrations of $\mathrm{As}, \mathrm{Cd}, \mathrm{Cr}, \mathrm{Pb}, \mathrm{Ni}$ and $\mathrm{Fe}$ were higher than recommended standards in $2.94 \%, 1.5 \%, 1.5 \%, 29.4 \%, 4.4 \%$ and $4.7 \%$ of groundwater samples, respectively. Groundwater in the study area can be classified between not contaminated $(<1)$ to very highly contaminated $(\mathrm{CI}>5)$ based on the contamination index. Highly contaminated samples were within dumpsites and industrial areas. The land-use activities have a direct or indirect impact on groundwater quality. The apparent sources of groundwater pollutants include industrial discharge, effluents, leachates and municipal wastes. The result of total health risk index for both ingestion and dermal exposure to water showed values far $>1$ for all the toxic elements and generally pose non-carcinogenic health risk hazards for child and adult population in the study area. THI for samples from residential, market, industrial and dumpsites showed mean values of (9.60 and 3.75), (14.17 and 5.37), (9.8 and 3.4) and 95.44 and 37.48) for child and adult population, respectively. The degree of contamination in groundwater showed the following trends: dumpsite $>$ industrial $>$ markets $>$ residential in the study area.
\end{abstract}

Keywords Contamination $\cdot$ Deficiency $\cdot$ Groundwater $\cdot$ Lagos and toxicity

\section{Introduction}

Groundwater is the most available source of drinking water in the developing parts of the world like Nigeria, and this is based on the fact that presently about $90 \%$ of the citizens make use of groundwater for drinking and other domestic purposes. It is, therefore, necessary for groundwater to be safe from any form of contamination. Groundwater is also essential for industrial and agricultural activities; hence, very vital for the growth and economic development of every nation (Sojobi et al. 2014).

Abiodun Mary Odukoya

amodukoya@unilag.edu.ng

1 Department of Geosciences, University of Lagos, Lagos, Nigeria
Groundwater contamination from prolonged exposure to environmental pollution is responsible for about $80 \%$ of the diseases and mortality from this part of the world (WHO 1998). The composition of groundwater plays a significant role in the determination of quality. Groundwater composition comprises of major and trace elements and can further be classified as essential and toxic elements. Essential elements support the main metabolic activities in the human system, and the deficiencies of these elements can lead to many health issues. In contrast, toxic elements are all detrimental to the health of man and animal. The toxic elements can get to the human system via oral ingestion by drinking, dermal absorption and inhalation (Wu et al. 2009). Inhalation is the least path of exposure with regards to water contamination.

The presence of Potentially Toxic Elements (PTEs) like lead, arsenic, cadmium, chromium, nickel, zinc, copper, 
manganese, etc., in groundwater has become a severe threat to both the environment and human health and hence a global problem. These PTEs can be derived from both natural (weathering of bedrocks, volcanic activities) and anthropogenic (industrial and agricultural activities, dumpsites, mining, etc.) sources and later pollute or contaminate both surface and groundwater (Khan et al. 2013). These toxic elements are the cause of many health problems, especially cancer of different human organs like liver, kidney, heart, lungs, etc.

Lagos is a megacity with the most significant number of industries in Nigeria. The ever-increasing population in Lagos also contributed to an increase in urbanisation, industrialisation and invariably water contamination due to overexploitation (Odukoya and Akande 2015). Freshwater scarcity is a global problem; therefore, there is an urgent need to design a programme for groundwater monitoring and regulation (USEPA 2017).

Lagos, Southwest Nigeria, has continued to experience a growing population and increased industrial activities since its foundation in 1967. Lagos abstracts over 180 million-gallon groundwater per day for both industrial and domestic use which contribute to the deterioration of groundwater resource (Odukoya et al. 2018). Water quality analyses remain a focal point in the groundwater investigation. Therefore, monitoring of the levels and trends of quality parameters that are influenced by geology and various anthropogenic activities become more feasible. Researches in medical geology have shown evidence of health risks with regard to trace elements exposure in different parts of the world such as Europe, America, Asia and some Africa countries. Deficiency of essential elements like $\mathrm{Ca}$, Se and $\mathrm{Mg}$ in groundwater has been cited as the principal cause of different heart problems. Overexposure to toxic elements is associated with many diseases ranging from cancer to heart problems all over the globe.

Many studies have confirmed the effect of anthropogenic contamination in groundwater composition and the health risks (Li et al. 2010, Khan et al. 2013, Odukoya 2015 and Odukoya et al. 2018). Past works on groundwater quality in Lagos and even the entire country at large have been minimal. There is no emphasis on the concentration of both essential and toxic elements in groundwater based on the deficiencies and toxicity of these elements. The outbreak of different types of cancer in some parts of Lagos is due to groundwater contamination, and the possible causes are yet to be determined. The objective of this research is to carry out a geochemical assessment of groundwater in some part of Lagos, southwest Nigeria with regard to the concentration of essential and PTEs present in groundwater and the health implications.

\section{Material and methodology}

\section{Study area}

This study area is located in Lagos, south-western Nigeria, the most populated and industrialised city in Nigeria and West Africa. It lies within latitude $6^{\circ} 30^{\prime}$ to $6^{\circ} 43^{\prime} \mathrm{N}$ and longitude $3^{\circ} 30^{\prime}$ to $3^{\circ} 27^{\prime} \mathrm{E}$ (Fig. 1). The population of Lagos is estimated to be 9 million. However, some people believe that the population can be double this amount, and this makes Lagos the largest city in Africa based on population (World Population Review 2019). The rapid growth in population, urbanisation and industrialisation has further enhanced the level of groundwater contamination in the area. Lagos vegetation is Tropical Swamp Forest which consists of the Freshwater and Mangrove Swamp Forests due to the double rainfall pattern of the study area. Over $40 \%$ of Lagos is covered by water, with an additional 12\% subjected to seasonal flooding (Iwugo et al. 2003). However, the entire location of the study area has been disturbed by the human civilisation, which majorly includes the construction of buildings and roads, thus leaving the area in an unnatural state.

The climate can be classified as a dry and wet season. There is a regular rainy season between April to November and the dry season from December to March. Harmattan period is between December and early February (EIA report, Procter and Gambie 2010). Lagos and Lekki Lagoon are the two drainage systems in the study area and are fed by Rivers Oni, Oshun and Saga in the northern parts of the lagoon (Emmanuel and Chukwu 2010).

The geology of the study area is within Coastal Plain Sand of Dahomey Basin, which falls within the sedimentary area of Nigeria. The geology of the study area which consists of sands and gravels with thin shale/clay interbeds with lignite of Miocene to Recent age is very porous and forms a multi-aquifer system (Longe et al. 1987; Oteri and Atolagbe 2003). There are four types of the aquifer in the study area, namely the Abeokuta group, Ewekoro formation, Coastal Plain Sands (CPS) and Recent sediment aquifers (Longe et al. 1987). The primary aquifer is the Coastal Plain Sands which can further be categorised into four: recent sediments $(<2 \mathrm{~m})$, upper continental plain sands $(<30 \mathrm{~m})$, lower coastal plain sands $(200-250 \mathrm{~m})$ and Abeokuta Formation which is the basement (Longe 2011).

\section{Sampling and analysis}

Groundwater from boreholes and hand-dug wells were collected from different locations in April 2017 (Fig. 1). The study area includes industrial, residential, markets 


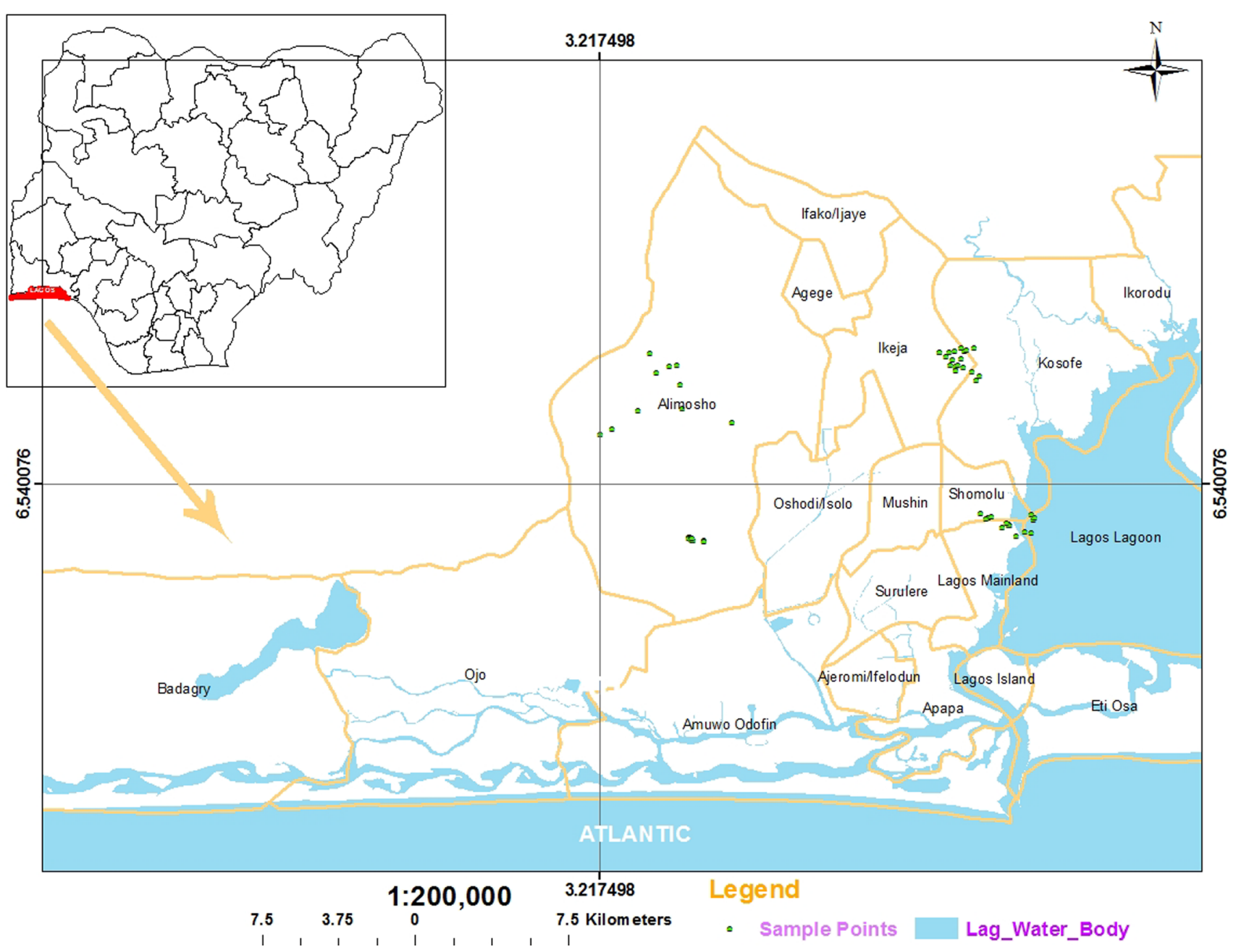

Fig.1 Sample location map of the study area

and dumpsite areas. The average depth to the groundwater table in the study area is $16 \mathrm{~m}$, and sampling was with polyethene bottles of $1 \mathrm{~L}$ capacity, sterilised before sampling. Sample collection was following standard guidelines outlined by APHA (1995) and Setpoint laboratories (watericon.co.za). The samples were collected using appropriate equipment and standard collection procedures. GPS was used to determine sample location points. The sampling bottles were kept in the refrigerator (at $4{ }^{\circ} \mathrm{C}$ ) and later sent to the laboratory for geochemical analysis. The geochemical analysis took place in ACME Laboratories, Ontario, Canada, using inductively coupled plasma-mass spectrometer (ICP-MS) method to determine major and trace elements. The recovery rate for all the metals based on the quality assurance ranged between 90 and $110 \%$.

\section{Results and interpretation}

\section{Essential elements}

This study investigated the quality of groundwater and health impacts on residents based on the concentration of major and trace elements in some parts of Lagos, southwest Nigeria. Sixty-seven boreholes and wells samples were collected from different parts of Lagos based on land use which includes residential, industrial, markets and some places with point source contamination like dumpsites. The essential elements analysed included $\mathrm{Ca}$, $\mathrm{Fe}, \mathrm{K}, \mathrm{Mg}, \mathrm{Na}$ and $\mathrm{Se}$.

Calcium is one of the essential macro minerals required for human body metabolic activities. The concentration of $\mathrm{Ca}$ in $\mathrm{mg} / \mathrm{l}$ ranged from 8.86 to $27.93,13.84-333.3$, 
Table 1 Summary of concentration of essential elements in groundwater

\begin{tabular}{lllllll}
\hline & & $\mathrm{Ca}(\mathrm{mg} / \mathrm{l})$ & $\mathrm{Fe}(\mathrm{mg} / \mathrm{l})$ & $\mathrm{Mg}(\mathrm{mg} / \mathrm{l})$ & $\mathrm{Na}(\mathrm{mg} / \mathrm{l})$ & $\mathrm{Se}(\mathrm{mg} / \mathrm{l})$ \\
\hline Residential & Min & 8.86 & 10 & 0.38 & 11.9 & 0.5 \\
& Max & 27.93 & 772 & 10.56 & 107.13 & 6.9 \\
& Mean & 18.03 & 189.78 & 4.46 & 55.49 & 2.84 \\
Market & Min & 13.84 & 10 & 2.26 & 19.53 & 0.5 \\
& Max & 333.3 & 772 & 590.4 & 3643.1 & 6.5 \\
& Mean & 71.97 & 245.45 & 63.30 & 411.05 & 2.32 \\
Industrial & Min & 0.31 & 10 & 0.11 & 19.97 & 0.5 \\
& Max & 28.3 & 416 & 27.49 & 275.2 & 3.6 \\
Dumpsite & Mean & 22.41 & 84.57 & 27.18 & 210.4 & 1.22 \\
& Min & 0.84 & 10 & 0.41 & 3.93 & 0.5 \\
\%age of samples with deficiency & & 83 & 0 & 80 & 0 & 27 \\
\%age of samples with toxicity & & 05 & 20 & 10 & 20 & 0 \\
\hline
\end{tabular}

and industrial areas were above $50 \mathrm{mg} / \mathrm{l}$ recommended by WHO 2012. $80 \%$ of the samples from all the study area were less than $10 \mathrm{mg} / 1$ recommended for drinking water and therefore are deficient in Mg. Magnesium deficiency can cause heart problems, diabetes, anxiety, premenstrual syndrome and migraine.

The concentration of sodium in the groundwater within residential, market, industry and dumpsites areas in $\mathrm{mg} / \mathrm{l}$ were 11.9-107.13, 19.53-3643.1, 19.97-227, 506 and 3.93-1443.3, respectively (Table 1, Fig. 2). The WHO and Nigerian standards for $\mathrm{Na}$ is $200 \mathrm{mg} / \mathrm{l}$ for healthy people and $20 \mathrm{mg} / \mathrm{l}$ for those with high blood pressure. $20 \%$ of groundwater samples, which were mostly from industrial areas were above $200 \mathrm{mg} / \mathrm{l}$ while $93 \%$ were above $20 \mathrm{mg} / \mathrm{l}$. The high concentration of $\mathrm{Na}$ can cause kidney damage, high blood pressure, sneezing and coughing. Deficiency of sodium is associated with weakness, dehydration, cramps and low blood pressure (Rose et al. 2000).

The concentration of iron in the study area ranged in $\mathrm{mg} / \mathrm{l}$ between 10 and 772, 10-772, 10-416 and 10-21,675 for residential, market, industry and dumpsites, respectively. $20 \%$ of samples were higher than the recommended standard, which can cause gastrointestinal upset such as nausea, cramping, vomiting and constipation. The deficiency of this element can cause anaemia.

Se ranged between 0.5 and $6.9,0.5-6.5,0.5-3.6$ and $0.5-27$ in $\mathrm{mg} / \mathrm{l}$ within residential, market, industry and dumpsites areas, respectively. All the groundwater samples in the study area showed a deficiency of Se and were lower than $10 \mu \mathrm{g} / 1$ recommended by WHO guidelines to prevent deficiency. Se deficiency can cause cardiovascular diseases, cancer, thyroid problems and mental retardation (Tebbutt 1983). ket, industry and dumpsites areas, respectively (Table 1 and Fig. 2). Groundwater samples within the only market 
Fig. 3 Hardness of water in the study area

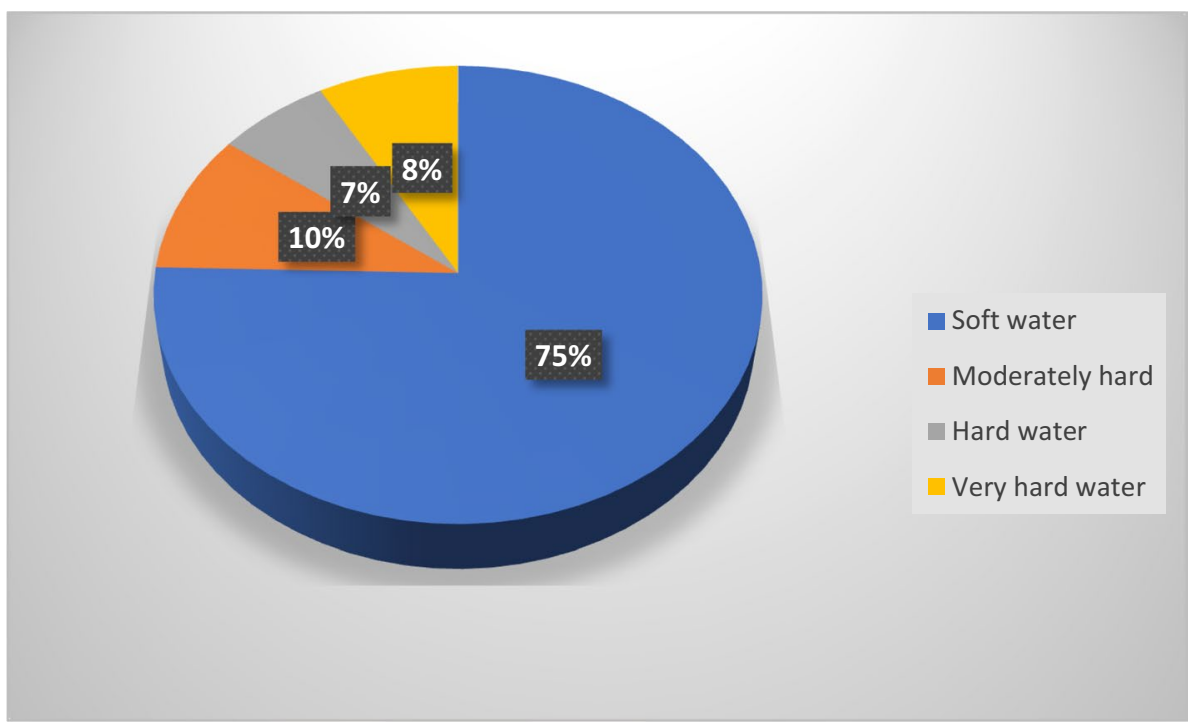

Table 2 Summary of results for potentially toxic elements in water

\begin{tabular}{|c|c|c|c|c|c|c|c|c|c|c|}
\hline \multirow[t]{2}{*}{ PTEs (ppb) } & \multicolumn{2}{|c|}{ Residential } & \multicolumn{2}{|l|}{ Market } & \multicolumn{2}{|c|}{ Industrial } & \multicolumn{2}{|c|}{ Dumpsite } & \multirow[t]{2}{*}{ WHO Guideline } & \multirow{2}{*}{$\begin{array}{l}\text { \%age } \\
\text { above } \\
\text { standard }\end{array}$} \\
\hline & Mean & Range & Mean & Range & Mean & Range & Mean & Range & & \\
\hline As & 1.05 & $0.5-4.2$ & 1.65 & $0.5-16.42$ & 0.75 & $0.5-4.3$ & 9.25 & $0.5-173$ & 10 & 2.94 \\
\hline $\mathrm{Cd}$ & 0.12 & $0.05-0.2$ & 0.14 & $0.05-0.5$ & 0.16 & $0.05-0.42$ & 0.98 & $0.09-4.4$ & 3 & 1.5 \\
\hline $\mathrm{Cr}$ & 2.95 & $0.5-8.7$ & 3.09 & $1.1-6.6$ & 3.16 & $0.5-14.6$ & 66.14 & $0.5-1171$ & 50 & 1.5 \\
\hline $\mathrm{Cu}$ & 4.78 & $0.8-9.5$ & 6.94 & $2.5-24$ & 35.78 & $1.2-157$ & 41.62 & $2.3-605$ & 1000 & 0 \\
\hline $\mathrm{Hg}$ & 0.46 & $0.1-1.2$ & 0.01 & $0.1-0.1$ & 0.1 & $0.1-0.1$ & 0.32 & $0.1-4$ & 1 & 3 \\
\hline $\mathrm{Li}$ & 1.19 & $0.3-2.4$ & 1.68 & $0.1-4.3$ & 3.97 & $0.3-12.8$ & 2.69 & $0.5-12$ & & 0 \\
\hline $\mathrm{Pb}$ & 3.3 & $0.2-13.1$ & 0.97 & $0.2-2.4$ & 15.5 & $0.1-76.8$ & 31.02 & $1.2-485$ & 10 & 29.4 \\
\hline $\mathrm{Se}$ & 3.0 & $0.5-6.9$ & 2.11 & $0.5-6.5$ & 1.0 & $0.5-3.6$ & 3.7 & $0.5-27$ & 50 & 0 \\
\hline $\mathrm{Zn}$ & 101.8 & $2.5-889.7$ & 15.11 & $3.6-48.1$ & 371.75 & $7.1-2365.1$ & 207.47 & $4.1-3777$ & 3000 & 0 \\
\hline $\mathrm{Ni}$ & 2.76 & $0.4-4.2$ & 12.25 & $0.7-103$ & 7.1 & $0.7-28.4$ & 32.65 & $0.4-604$ & 20 & 4.4 \\
\hline $\mathrm{Fe}$ & 2.53 & $10-772$ & 220.4 & $10-772$ & 56.6 & $10-416$ & 2655.3 & $10-21,675$ & 300 & 14.7 \\
\hline
\end{tabular}

\section{Groundwater hardness in the study area}

Water hardness is the amount of calcium carbonate dissolved in water in $\mathrm{mg} / \mathrm{l}$. Groundwater in the study area can be categorised as soft water, moderately hard, hard and very hard in 75\%, 10\%, 7\% and 8\%, respectively (Fig. 3). The samples within dumpsite and industrial areas were soft water while those within residential areas were hard water. Soft water can cause different cardiovascular diseases. World Health Organisation (WHO) has recommended drinking of the water of at least $170 \mathrm{mg} / \mathrm{l} \mathrm{hard-}$ ness as $\mathrm{CaCO}_{3}$ (Committee of Medical Aspect of Food Policy, COMA 1994). Only $15 \%$ of the water samples, mostly within residential areas, were within the WHO recommended standard and are between hard and very hard water (Fig. 3).

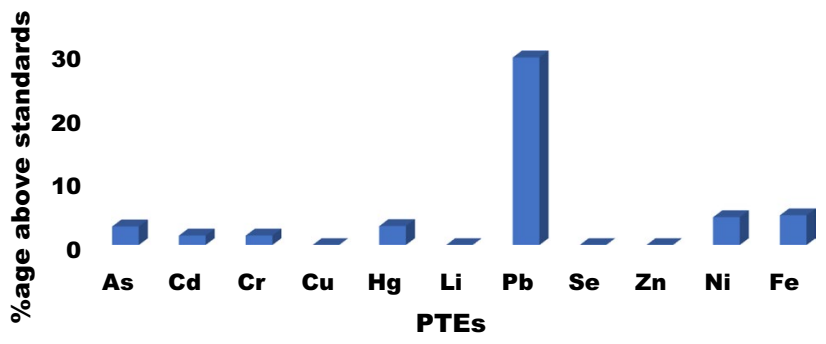

Fig. 4 Percentage of PTEs above WHO Values

\section{Potentially toxic elements in groundwater}

Eleven potentially toxic elements (PTEs) were analysed, and the result summary is presented in Table 2 with WHO, 2012 standard and percentage of samples above the standards. The 
values of $\mathrm{Cu}, \mathrm{Hg}, \mathrm{Se}, \mathrm{Zn}$ and $\mathrm{Li}$ were less than WHO 2012 guidelines for all the samples. $\mathrm{As}, \mathrm{Cd}, \mathrm{Cr}, \mathrm{Pb}, \mathrm{Ni}$ and $\mathrm{Fe}$ were above recommended guidelines in $2.94 \%, 1.5 \%, 1.5 \%$, $29.4 \%, 4.4 \%$ and $4.7 \%$ of water samples, respectively (Fig. 4). Samples above the recommended standards were those taken around the market, industrial and dumpsite areas. The concentration of toxic elements in the residential area was within WHO standards except for $\mathrm{Pb}$ and $\mathrm{Ni}$. The variation maps of the PTEs in the study area are shown in Fig. 5 and showed areas with high concentration.

\section{Assessment of contamination in groundwater samples}

Contamination Index (CI) is used to measure the anomalous concentration of elements due to contamination as presented in Eq. 1 (Sundaray et al. 2011) and different classification is shown in Table 3.

$\mathrm{CI}=\sum \mathrm{MC} / \mathrm{MAC}$

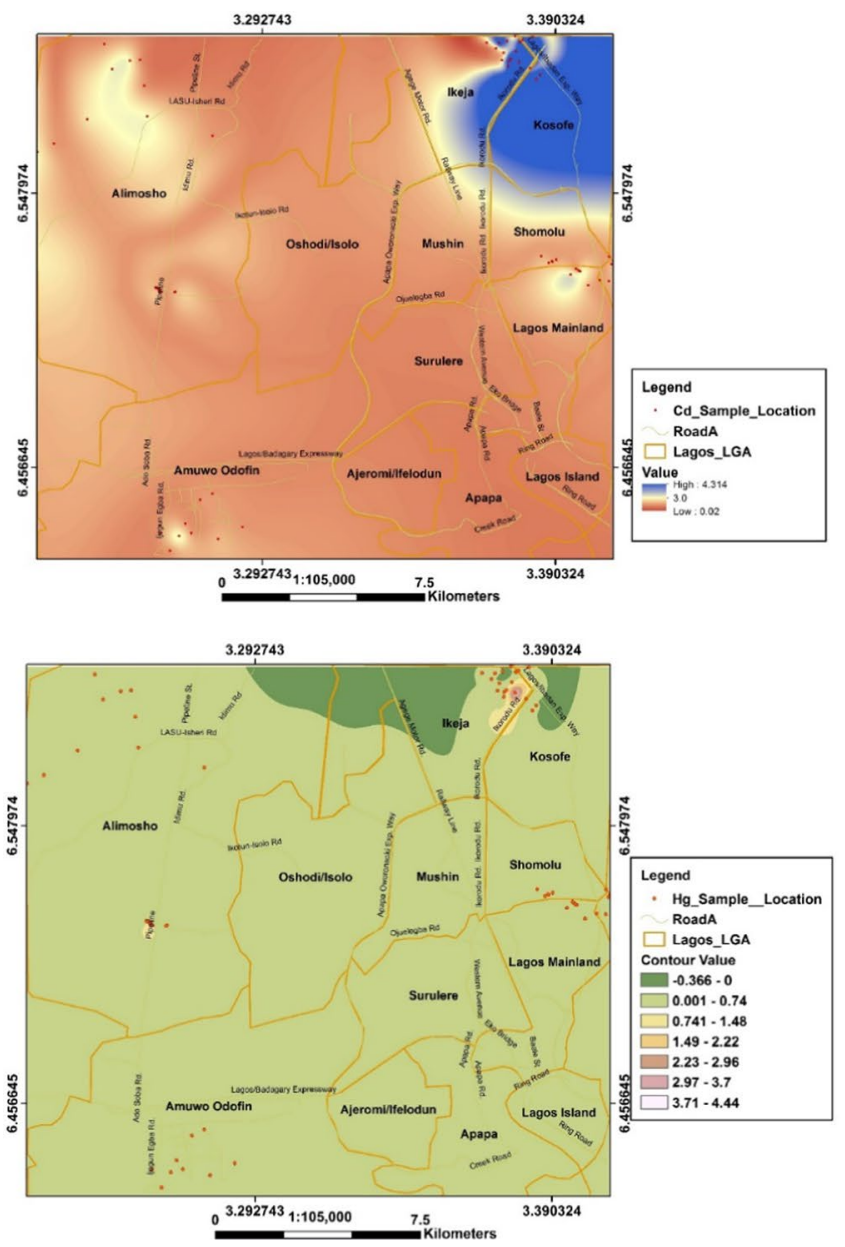

Table 3 Classification of contamination index

\begin{tabular}{ll}
\hline Contamination index $(\mathrm{CI})$ & Classification \\
\hline $\mathrm{CI}=<1$ & Not Contaminated \\
$\mathrm{CI}=1-5$ & Slightly Contaminated \\
$\mathrm{CI}>5$ & Highly Contaminated \\
\hline
\end{tabular}

$\mathrm{Mc}=$ concentration of element in groundwater sample, MAC $=$ Maximum Allowable Concentration of element recommended by WHO 2012 standard.

The result of Contamination Index (CI) showed that groundwater samples from all the study area could be classified between not contaminated $(<1)$ to very highly contaminated $(\mathrm{CI}>5)$. The very highly contaminated samples were those around the dumpsites, industries and markets while water with low contamination was within the residential area (Table 4, Fig. 6). As, $\mathrm{Cd}, \mathrm{Cr}, \mathrm{Pb}, \mathrm{Ni}$ and $\mathrm{Fe}$ were responsible for the groundwater contamination.
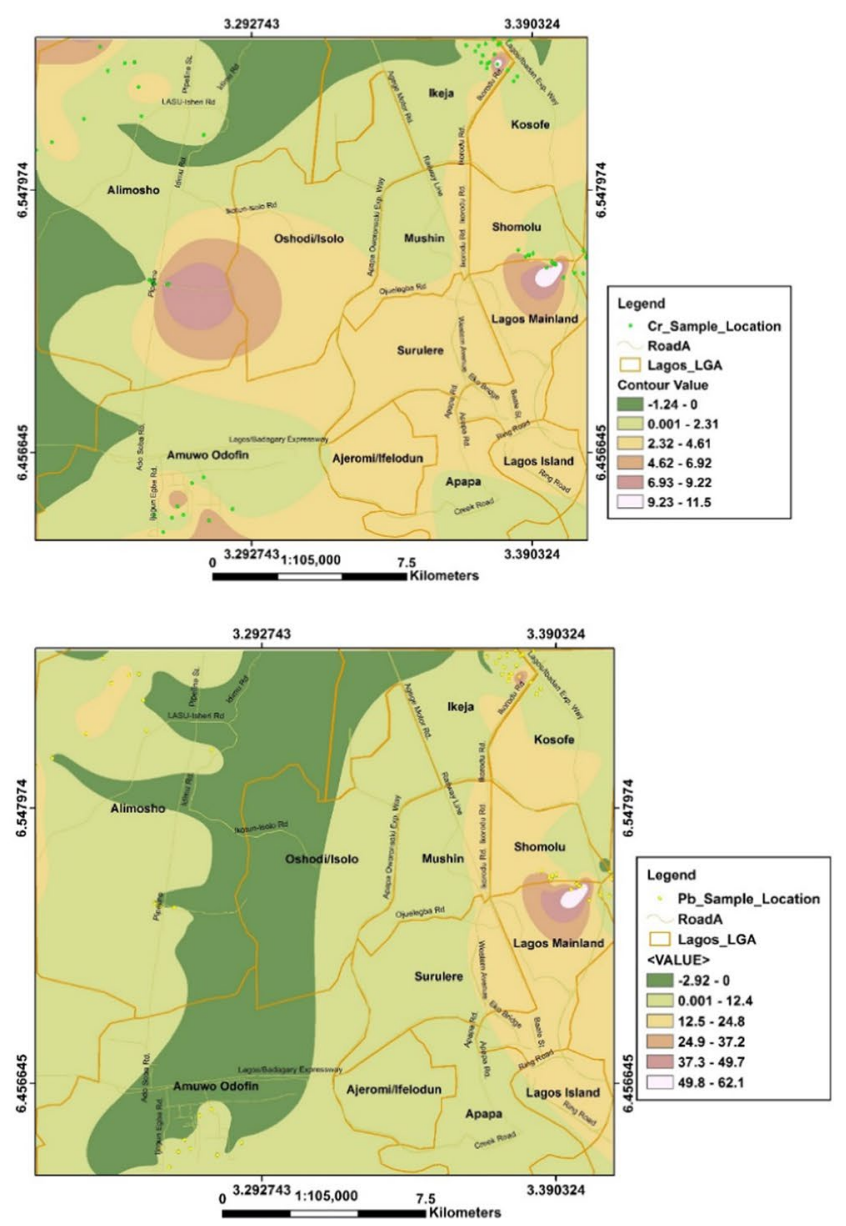

Fig. 5 Geochemical maps of some PTEs in the groundwater of study area 
Table 4 Summary results for contamination index of groundwater in the study area

\begin{tabular}{|c|c|c|c|c|c|c|c|}
\hline \multicolumn{2}{|c|}{ Residential } & \multicolumn{2}{|c|}{ Market } & \multicolumn{2}{|c|}{ Industrial } & \multicolumn{2}{|c|}{ Dumpsite } \\
\hline Mean & Range & Mean & Range & Mean & Range & Mean & Range \\
\hline \multicolumn{8}{|c|}{ Contamination index } \\
\hline 1.85 & $0.21-5.79$ & 2.51 & $0.22-12.4$ & 18.19 & $0.24-172.68$ & 16.5 & $0.33-197.5$ \\
\hline
\end{tabular}

Fig. $6 \mathrm{CI}$ of the groundwater in the study area

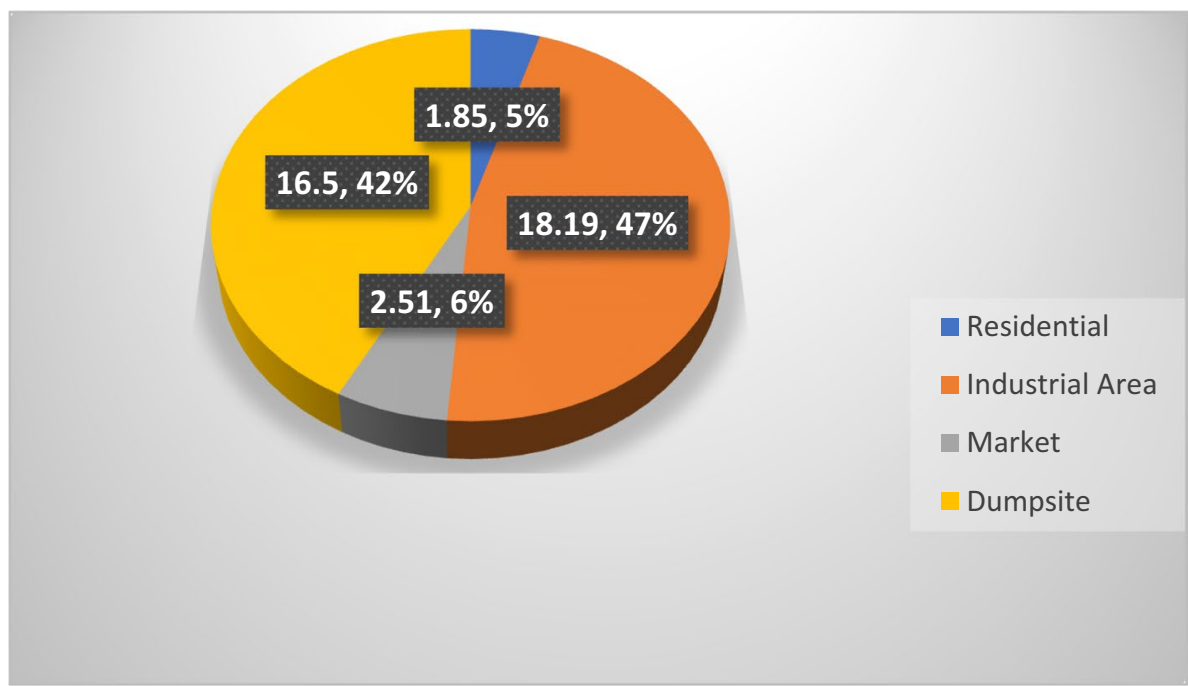

\section{Health risk assessments in groundwater samples}

Exposure pathways of humans to contaminated groundwater include ingestion, dermal absorption and inhalation. The first two paths are more relevant in contaminated water (Liyuan et al. 2010). The formulae to determine these two pathways are presented in Eqs. 2 and 3 proposed by Miguel et al. 2007 and presented in Wu et al. 2009. The parameters to calculate the health risk assessment can be found in Odukoya et al. 2018.

Chronic Daily Intake $\left(\mathrm{CD}_{\text {Ingestion }}\right)=\frac{\mathrm{Cw} * \mathrm{IR} * \mathrm{ABSg} * \mathrm{EF} * \mathrm{ED}}{\mathrm{BW} * \mathrm{AT}}$

Chronic Daily Intake $\left(\mathrm{CD}_{\text {Dermal }}\right)$

$$
=\frac{\mathrm{Cw} * \mathrm{SA} * \mathrm{Kp} * \mathrm{ABSd} * \mathrm{ET} * \mathrm{EF} * \mathrm{ED} * C F}{\mathrm{BW} * \mathrm{AT}}
$$

Hazard Quotients (HQ). Exposure to toxic elements in water can lead to the potential non- carcinogenic human health risks. It can be determined through Hazard Quotients (HQ) using Eqs. 4 where CDI represented chronic daily intake of toxic metal in $\left(\mathrm{mg} \mathrm{kg}^{-1} \mathrm{~d}^{-1}\right)$ and RfD is the oral or dermal dose (USEPA 2009). Table 5 shows all the RfD values.

Total Health Risk index (HI) is the addition of all HQs from all the pathways (Saha et al. 2017). $i$ is the different exposure pathways such as ingestion and dermal. When $\mathrm{Hi}$ is greater than 1, it means there is a possibility of adverse health risk or need to investigate further (USEPA 2004, Sara et al. 2017).

Hazard Quotient $(\mathrm{HQ})=\frac{\mathrm{CDI}}{\mathrm{RfD}}$

$\mathrm{HI}=\sum_{i=1}^{n} \mathrm{HQi}$

\section{Assessment of human health risk based on exposure to toxic elements in groundwater}

The results of health risk assessments for all pathways calculated for adults and children in the study area are presented in Table 5.

\section{Hazard quotient (HQ)}

Tables 5 and 6 show the results of HQ based on ingestion and dermal exposure calculated for eight potentially toxic elements which are $\mathrm{Pb}, \mathrm{Zn}, \mathrm{Cd}, \mathrm{As}, \mathrm{Cu}, \mathrm{Cr}, \mathrm{Ni}$ and $\mathrm{Fe}$ in the groundwater of the study area for adult and child. Groundwater samples taken from industrial and dumpsite areas showed that HQ values of all the eight toxic elements were $>1$ for dermal and ingestion pathways in both children and adults' populations. These results showed that all the 

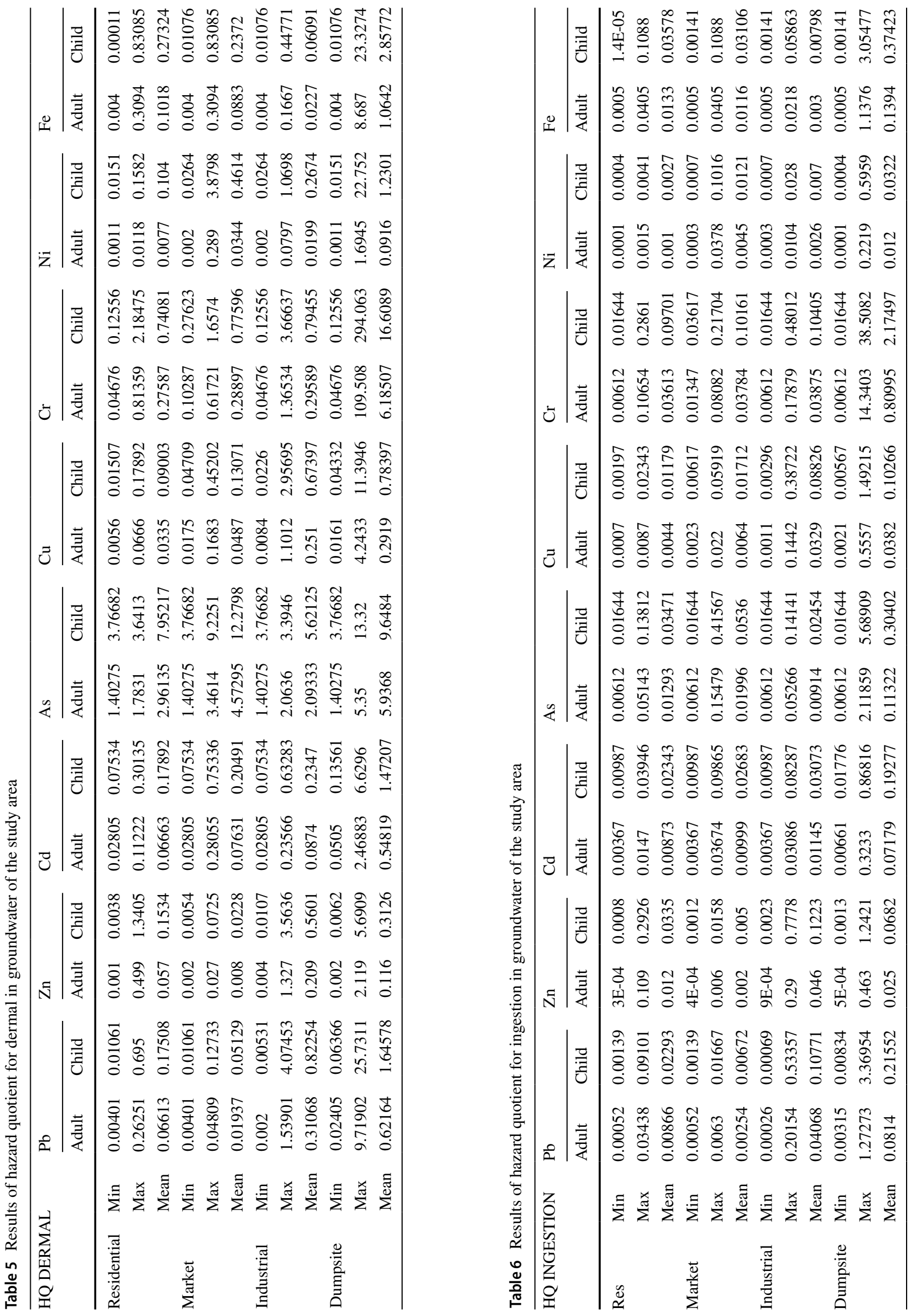
eight toxic elements in the groundwater around the industrial and dumpsite constitute dangerous health hazard through exposure to both pathways. Groundwater samples taken from residential and market areas showed that HQ values based on exposure by ingestion were $<1$ for all the eight PTEs and therefore posed no serious health hazard via ingestion exposure to the residents of the area. The values of HQ based on dermal exposure showed that $\mathrm{Zn}$ and $\mathrm{Cr}$ in children and $\mathrm{As}$ in both children and adults were $>1$ in groundwater taken from the residential area. Generally, all the eight toxic elements in groundwater within industrial and dumpsite areas posed non-carcinogenic adverse health risks to the residents of the area. Residents within residential and market areas are exposed to adverse non-carcinogenic health risks based on $\mathrm{Zn}, \mathrm{Cr}$, As and $\mathrm{Ni}$ in the groundwater from the two pathways (Tables 5 and 6).

\section{Health Index (HI)}

The non-carcinogenic health risk index (HI) based on exposure through ingestion for all the eight elements ranged from 0.02 to $0.37,0.03-0.38,0.02-0.91$ and $0.03-20.43$ for adults and $0.05-0.98,0.07-1.03,0.05-2.49$ and $0.07-54.8$ for children in samples taken from the residential, market, industrial and dumpsite areas, respectively. HI via ingestion calculated for adults showed values $<1$ for all the samples except those taken within the dumpsite. The reverse is the case for children with $\mathrm{HI}>1$ for all the water samples except residential samples. The results indicated adverse non-carcinogenic health risk hazard in children for all the samples except those within residential areas. Only adults within the dumpsite area are exposed to adverse non-carcinogenic health risk hazards.

The non-carcinogenic health risk index (HI) based on dermal exposure for all the toxic elements $(\mathrm{Pb}, \mathrm{Zn}, \mathrm{Cd}, \mathrm{As}$, $\mathrm{Cu}, \mathrm{Cr}, \mathrm{Ni}$ and $\mathrm{Fe}$ ) ranged from 1.49 to $13.86,1.56-37.2$, 1.5-17.87 and 1.55-673.78 for adults and 4.01-37.33, $4.22-102.92,4.04-48.81$ and 4.17-1692.06 for children in samples taken from the residential, market, industrial and dumpsite areas, respectively. The HI (Dermal) of all the samples were $>1$ in both adults and children indicating values within non-carcinogenic harmful health risk hazard.

The total hazard index (Ing and Derm) for groundwater taken from dumpsite showed the highest values and followed the trend Dumpsite $>$ Industrial $>$ Market $>$ Residential. The results indicated that all the groundwater samples could cause adverse non-carcinogenic health risk hazard based on all the toxic elements when ingested orally and adsorbed dermally by children. The groundwater within dumpsite, industrial and market areas could cause different health hazard to the residents, especially the children. (Fig. 7a-c).

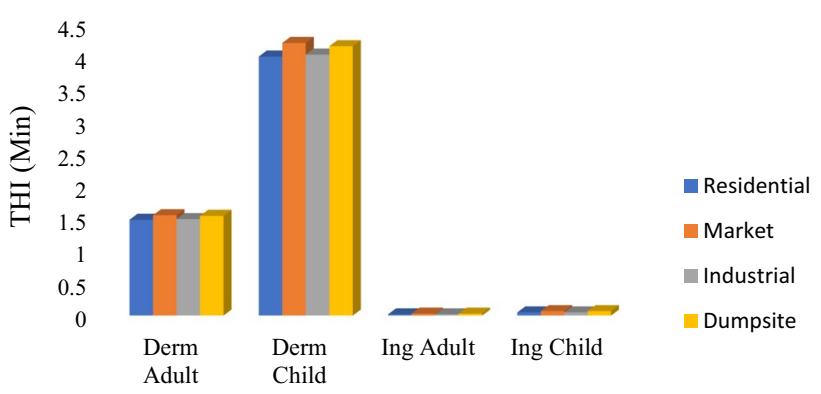

(a) THI values for Dermal and Ingestion in Adult and Child Population

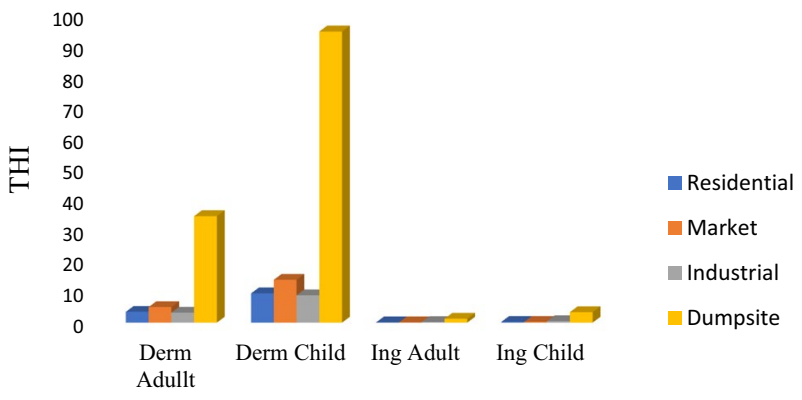

(b) THI Mean values for Dermal and Ingestion in Adult and Child

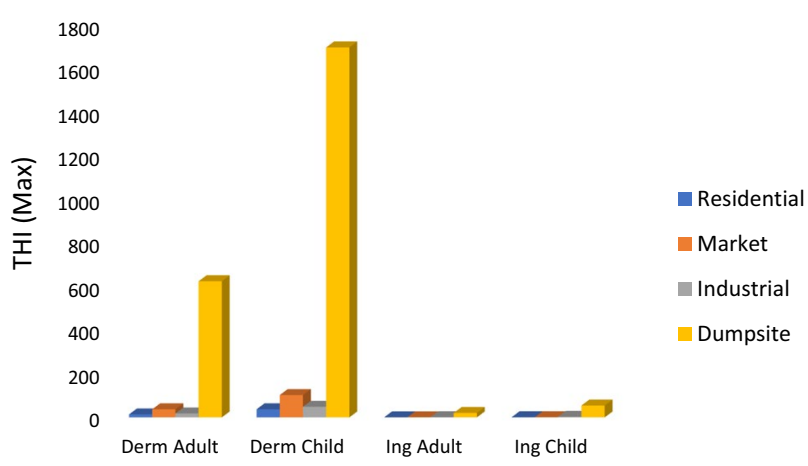

(c) THI Maximum values for Dermal and Ingestion in Child and Adult

Fig. 7 a.THI values for Dermal and Ingestion in Adult and Child Population. b THI Mean values for Dermal and Ingestion in Adult and Child. c THI Maximum values for Dermal and Ingestion in Child and Adult

\section{Conclusion}

The purpose of the study was to investigate the groundwater quality with emphasis on the health risk assessment of both essential and eight potentially toxic elements (PTEs) in groundwater within Lagos, southwest Nigeria, based on land use. Sixty-seven groundwater samples were collected from different parts of Lagos based on land use which includes residential, industrial, markets and some places with point source contamination like dumpsites.

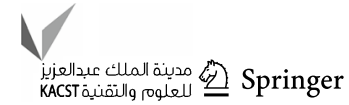


The essential and PTEs elements analysed included $\mathrm{Ca}$, $\mathrm{Fe}, \mathrm{K}, \mathrm{Mg}, \mathrm{Na}, \mathrm{Se}$ and $\mathrm{Pb}, \mathrm{Zn}, \mathrm{Cd}, \mathrm{As}, \mathrm{Cu}, \mathrm{Cr}, \mathrm{Ni}, \mathrm{Fe}$, respectively.

1. The essential elements like $\mathrm{Ca}, \mathrm{Mg}$ and Se showed deficiencies in $83 \%, 80 \%$ and $100 \%$ of the groundwater samples, respectively. They can cause diseases like heart problems, impeded growth, fertility disorders and liver diseases.

2. $75 \%$ of groundwater samples in the study area can be classified as soft, $10 \%$ as moderately hard, $7 \%$ as hard and $8 \%$ as very hard water. Most of the soft groundwater were located around the dumpsites and industrial areas, while the hard groundwater samples were within residential areas. There is a link between soft water and cardiovascular diseases in different countries around the world.

3. The values of $\mathrm{Cu}, \mathrm{Hg}, \mathrm{Li}, \mathrm{Se}$ and $\mathrm{Zn}$ for all the groundwater samples were below the WHO, 2012 standard. $\mathrm{As}, \mathrm{Cd}, \mathrm{Cr}, \mathrm{Pb}, \mathrm{Ni}$ and $\mathrm{Fe}$ were above recommended standard in $2.94 \%, 1.5 \%, 1.5 \%, 29.4 \%, 4.4 \%$ and $4.7 \%$ of water samples, respectively. Samples above recommended standards were those taken around the market, industrial and dumpsite areas. All the toxic elements in the residential area were within WHO standards except for $\mathrm{Pb}$ and $\mathrm{Ni}$.

4. The result of Contamination Index showed that groundwater samples from all the study area could be classified between not contaminated $(<1)$ to very highly contaminated $(\mathrm{CI}>5)$. Highly contaminated samples were within dumpsites and industrial areas.

5. Some of the water samples taken from the study areas showed non-carcinogenic health hazards with some of the toxic elements when ingested orally by children. Only some water samples taken within dumpsites can be hazardous when ingested orally by adults.

6. Some of the water samples in the study area showed non-carcinogenic hazard with all the toxic elements when absorbed dermally by both children and adults.

7. It can, therefore, be concluded that land use in the study area affects groundwater quality. The level of contamination follows the trend dumpsite $>$ industrial $>$ markets $>$ residential. It has also led to the contamination of groundwater with $\mathrm{Mn}, \mathrm{Pb}, \mathrm{Zn}, \mathrm{Cd}, \mathrm{As}, \mathrm{Cu}, \mathrm{Ni}, \mathrm{Cr}$ and $\mathrm{Fe}$ and pose hazardous non-carcinogenic health risks to the health of residents especially around the dumpsites and industrial areas.

Funding The authors appreciate UNESCO through UNESCO/SIDA project for the award of ANESI's visiting fellowship for outstanding women Geoscientist Programme which enabled the corresponding author to visit Department of Geology, University of Johannesburg, South Africa where the manuscript was put together. The lead author also appreciates the entire staff of the Department of Geology, University of Johannesburg, South Africa, especially the Head of Department, Prof. Michiel de Kock and Prof. Hasina Mouri for making my stay exciting and comfortable.

\section{Declarations}

Conflict of interest The authors declare that they have no conflict of interest.

Ethical approval This research is compliance with the ethical standard of the research project.

Open Access This article is licensed under a Creative Commons Attribution 4.0 International License, which permits use, sharing, adaptation, distribution and reproduction in any medium or format, as long as you give appropriate credit to the original author(s) and the source, provide a link to the Creative Commons licence, and indicate if changes were made. The images or other third party material in this article are included in the article's Creative Commons licence, unless indicated otherwise in a credit line to the material. If material is not included in the article's Creative Commons licence and your intended use is not permitted by statutory regulation or exceeds the permitted use, you will need to obtain permission directly from the copyright holder. To view a copy of this licence, visit http://creativecommons.org/licenses/by/4.0/.

\section{References}

COMA (1994) Nutritional aspects of cardiovascular disease. Committee on Medical Aspect of Food Policy. London: HMSO. pp. 46:186

De Miguel E, Iribarren I, Chacón E, Ordoñez A, Charlesworth S (2007) Risk-based evaluation of 447 the exposure of children to trace elements in playgrounds in Madrid, (Spain). Chemosphere 66:505-513

Emmanuel BE, Chukwu LO (2010) Spatial distribution of saline water and possible sources of intrusion into a tropical freshwater lagoon and the transitional effects on the lacustrine ichthyofaunal diversity. Afr J Environ Sci Technol 4(7):480-491

Iwugo KO, D'Arcy B, Andoh R (2003) Aspects of Land-based pollution of an African Coastal Megacity of Lagos. Proceedings of the International Specialized IWA Conference, Dublin, Ireland

Khan S, Shahnaz M, Jehan N, Rehman S, Shah MT (2013) Drinking water quality and human health risk in Charsadda district, Pakistan. J Clean Prod 60:93-101. https://doi.org/10.1016/j.jclep ro.2012.02.016

Li S, Zhang Q (2010) Risk assessment and seasonal variation of dissolved trace elements and heavy metals in the upper Ham River China. J Hazard Mater 181:1051-1058

Longe EO, Malomo S, Olorunnwo MA (1987) Hydrogeology of Lagos metropolis. J Afr Earth Sci 6(2):163-174

Odukoya AM (2015) Geochemical and quality assessment of groundwater in some Nigerian basement complex. Int J Environ Sci Tech 12(11):3643-3656

Odukoya AM, Olobaniyi SB, Oluseyi TO (2018) Assessment of potentially toxic elements pollution and human health risk in soil of Ilesha Gold Mining Site, Southwest Nigeria. Indian J Geochem 91(6):645-764

Oteri AU \& Atolagbe FP (2003) Saltwater intrusion into coastal aquifers in Nigeria. In: Proceeding of The Second International 
Conference on Saltwater Intrusion and Coastal Aquifers - Monitoring, Modeling, and Management. Mérida, Yucatán, México. March 20-April 2, 2003.S

Procter and Gambie (2010). Environmental Impact Assessment, Agbara Estate report

Rose B, Narins R (2000) Clinical physiology of acid-base and electrolyte disorders. McGraw-Hill Companies, New York

Saha N, Rahman MS, Ahmed MB, Zhou JL, Ngo HH, Guo W (2017) Industrial metal pollution in water and probabilistic assessment of human health risk. J Environ Manag 185:70-78. https://doi. org/10.1016/j.jenvman.2016.10.023

Sojobi AO, Oyegoke SO, Eniola J, Oyetayo F, Lawal T (2014) 3-D modelling of protection works for an aspect of Lagos Coast. J Emerg Trends Eng Appl Sci (JETEAS) 5(2):68-73

Sundaray SK, Nayak BB, Lin S, Bhatta D (2011) Geochemical speciation and risk assessment of heavy metals in the river estuarine sediments - a case study. Mahanadi Basin, India. J Hazard Mater 186: $1837-1846$

Tebbutt TA (1983) Relationship between natural water quality and health. Technical Document in Hydrology. International Hydrological Programme. UNISCO, Paris

U.S. EPA (2009). Cleaning up the Nation's Waste Sites: Markets and Technology Trends. Washington, DC: U.S. Environmental Protection Agency. Accessed 30 January 2009. http://www.clu-in.org/ download/market/2004market.pdf.

WHO (2012) Guidelines for drinking water quality, fourth edition. www.who.int/water_sanitation_health/publications/dwqchapter s/en
World Population Review (2019) http://worldpopulationreview.com/ countries/Africa-population

Wu B, Zhao DY, Jia HY, Zhang Y, Zhang XX, Cheng SP (2009) Preliminary risk assessment of trace metal pollution in surface water from Yagtze River in Nanjing section, China. Bull Environ Contam Toxicol 82(4):405

Longe EO (2011) Groundwater Resources Potential in the Coastal Plain Sands Aquifers, Lagos, Nigeria. Res J Environ Earth Sci 3(1):1-7

WHO (2006) Guidelines for drinking water quality. First Addendum to Third Edition, vol 1. https://www.who.int/water_sanitation_healt h/dwq/secondaddendum20081119.pdf

U.S. Environmental Protection Agency (EPA) (2017) Water quality standards handbook: chapter 3: water quality criteria. EPA823-B-17-001. EPA Office of Water, Office of https://www.epa. gov/sites/production/files/2014-10/documents/handbook-chapt er3.pdf

USEPA (2004) Guidelines for water reuse. U.S. Agency for International Development Washington, DC. Accessed November 2019. https://sswm.info/sites/default/files/reference_attachments/30006 MKD.pdf

Liyuan C, Zhenxing W, Yunyan W, Xie W (2010) Ingestion risks of metals in groundwater based on TIN model and dose-response assessment - A case study in the Xiangjiang watershed, centralsouth China. Sci Total Environ 408(16):3118-24

Publisher's Note Springer Nature remains neutral with regard to jurisdictional claims in published maps and institutional affiliations. 